\title{
DYNAMIC HYDRODISTENTION CLASSIFICATION OF THE URETER AND THE DOUBLE HIT METHOD TO CORRECT VESICOURETERAL REFLUX
}

\author{
Wolfgang H. Cerwinka', Hal C. Scherz and Andrew J. Kirsch \\ Children's Healthcare of Atlanta. Emory University School of Medicine. Atlanta. USA.
}

\begin{abstract}
Summary.- OBJECTIVES: The objective of this monograph is to familiarize the reader with dynamic hydrodistention classification of the ureter and Hydrodistention Implantation Technique (HIT) methodology for the endoscopic correction of vesicoureteral reflux (VUR). The indications, current success rates, complications, and potential future applications of these methods are reviewed.
\end{abstract}

METHODS: Hydrodistention (HD) of the ureteral orifice and distal ureter permits visualization of the intraureteral submucosal injection site and assessment of the degree of ureteral coaptation. We have designated 4 levels of $\mathrm{HD}$. HO denotes absence of ureteral dilation, $\mathrm{HI}$ indicates dilation of the ureteral orifice only. $\mathrm{H} 2$ allows visualization of the intramural ureter, and $\mathrm{H} 3$ allows visuaAtlanta, GA 30342. USA. lization of the extramural ureter. The Double HIT method is a systematic technique that utilizes HD to both classity the ureter and gauge the degree of ureteral coaptation secondary to bulking during endoscopic injection. The needle is inserted at the mid ureteral tunnel at the 6 o'clock position. The first injection coapts the detrusor tunnel (until HT or HO is achieved), while a second implant within the most distal intramural tunnel leads to complete coaptation of the ureteral orifice $(\mathrm{HO})$.

RESULTS: HD grade correlated significantly with VUR grade. Normal ureters rarely hydrodistended. While non-refluxing contralateral ureters demonstrated low HD grades, all contralateral ureters that subsequently developed VUR showed H2 or H3. The HIT method has not only been employed for primary VUR (90\% cure), but also for repeat endoscopic injections (90\%), VUR associated with paraureteral diverticula (8 1\%), complex cases such as post-reimplantation (88\%), neurogenic bladders (78\%), duplication anomalies (80\%), and in adults (88\%). Furthermore, injection of contralateral VURnegative but hydrodistending ureters may be treated to prevent new contralateral VUR. While decreasing success was seen with increasing VUR grade with the STING method, superior success rates have been realized with the HIT method.

CONCLUSIONS: The dynamic hydrodistention classification reflects the competency of the ureterovesical junction. The HIT and Double HIT methods achieve superior cure rates and are likely to become the method of choice for the treatment of primary as well as complex cases of VUR.

Keywords: Vesicoureteral reflux. Endoscopic injection. Hydrodistention. 
Resumen.- OBJETIVO: El objetivo de esta monografía es familiarizar al lector con la clasificación de la hidrodistensión dinámica del uréter y la metodología de la técnica de hidrodistensión-implante para la corrección endoscópica del reflujo vesicoureteral (RVU). Revisamos las indicaciones, la tasa de éxitos actual, sus complicaciones y las potencialesaplicaciones de estos métodos en el futuro.

MÉTODOS: La hidrodistensión del orificio ureteral y el uréter distal permite la visualización del sitio de inyección de la submucosa ureteral y la evaluación del grado de coaptación ureteral. Hemos designado cuatro niveles de hidrodistensión. HO ausencia de dilatación ureteral, H1 dilatación sólo del orificio ureteral, H2 permite la visualización del uréter intramural y H3 permite la visualización del uréter extramural. El método de doble hidrodistensión-implante es una técnica sistemática que utiliza la hidrodistensión para clasificar el uréter y evaluar el grado de coaptación ureteral después de la inyección endoscópica de sustancias de relleno. La aguja se inserta en el túnel medio ureteral a las 6 horarias. La primera inyección coapta el túnel en el detrusor (hasta conseguir $\mathrm{Hl}$ o $\mathrm{HO}$ ), mientras que una segunda inyección más distal en el túnel intramural lleva una coaptación completa del orificio ureteral $(\mathrm{HO})$.

RESULTADOS: El grado de hidrodistensión se correlacionó significativamente con el grado de RVU. Mientras que los uréteres contralaterales no refluyentes demostraban grados bajos de hiperdistensión, todos los uréteres que desarrollaron reflujo vesicoureteral posterior mostraban H2 o H3. El método de hidrodistensión-implante no se ha empleado sólo para RVU primario $190 \%$ de curaciones), sino también para inyecciones endoscópicas repetidas (90\%), RVU asociado con divertículo paraureteral $(81 \%)$, casos complejos como después de reimplante (88\%), vejiga neurógena (78\%), anomalías con duplicación (80\%), y en adultos (88\%). Además, el uréter contralateral no refluyente que presenta hidrodistensión puede tratarse para prevenir el RVU de novo. Mientras que con el método STING las tasas de éxito disminuyen al aumentar el grado del RVU, con el método de hidro distensión-implante se han visto mejores tasas de éxitos.

CONCLUSIONES: La clasificación de la hidrodistensión dinámica refleja la competencia de la unión ureterovesical. Los métodos de hidrodistensión-implante simple y doble consiguen tasas de curación superiores y probablemente se convertirán en el método de elección para el tratamiento del RVU primario y de los casos complejos.

Palabras clave: Reflujo vesicoureteral. Inyección endoscópica. Hidrodistensión.

\section{INTRODUCTION}

Vesicoureteral reflux (VUR) affects approximately $1 \%$ of children and can promote pyelonephritis, which may lead to significant sequelae such as renal scarring, hypertension, and renal failure (1). VUR is one of many treatable risk factors (e.g., dysfunctional elimination) in the development of urinary tract infection (UTI). Treatment intends to prevent pyelonephritis and to preserve renal function (2). Since the introduction of endoscopic treatment for VUR in 1981, and its first clinical application in 1984 as Subureteric Teflon Injection (STING), injection techniques and injectable agents have undergone considerable modifications $(3,4)$. In 2004, the modified STING procedure, later known as the Hydrodistention Implantation Technique (HIT) was introduced and is rapidly becoming the technique of choice world-wide achieving success rates of over $90 \%$ after a single treatment $(5,6)$.

The purpose of this monograph is to familiarize the reader with the Hydrodistention Implantation Technique and the dynamic hydrodistention classification. Indications, current success rates, complications, and potential future applications of these methods are reviewed.

\section{MATERIALS AND METHODS}

Cystoscopy is performed with a pediatric cystoscope with an off-set lens. An off-set lens permits direct passage of the needle in line with the ureter without bending the needle. The bladder is filled to less than half capacity to permit visualization of the ureter and avoid tension within the submucosal layer of the ureter secondary to overdistention. Hydrodistention (HD) is performed with the tip of the cystoscope placed at the ureteral orifice (UO), a pressured stream achieved by placing the irrigation bag approximately 1 meter above the bladder on full flow. HD of the distal ureter serves two purposes: It allows visualization of the intraureteral injection site and assessment of treatment progress. Ureteral HD is graded according to the extent of ureteral dilation (Figure 1). $\mathrm{HO}$ denotes absence of ureteral dilation. $\mathrm{Hl}$ indicates dilation of the $\mathrm{UO}$ only, whereas $\mathrm{H} 2$ allows visualization of the intramural ureter, and $\mathrm{H} 3$ visualization of the extramural ureter. Our data indicate that $\mathrm{HO}-\mathrm{Hl}$ is normal, while $\mathrm{H} 2-\mathrm{H} 3$ is abnormal and is associated with VUR and pyelonephritis (7).

The HIT method has employed dextranomer/ hyaluronic acid copolymer (Deflux®, Q-Med Scandinavia) as an injectable agent, which has been used in pediatric urology for over 10 years and is the preferred injectable agent due to its safety and efficacy 
(8). The needle is passed into the $U O$ and inserted at the mid ureteral tunnel at the 6 o'clock position. Sufficient bulking agent is injected to produce a bulge, which initially coapts the detrusor tunnel (until $\mathrm{HO}$ or $\mathrm{HI}$ is achieved), while a second implant within the most distal intramural tunnel leads to coaptation of the UO (until HO is achieved, approximately 1-1.5 $\mathrm{mL}$ ). Rarely, if the two intraureteric submucosal injections (Double HIT method) fail to coapt the ureter, a classic STING or a supraureteric injection is needed to achieve coaptation. The latter 2 injection sites are used more commonly in complex or redo cases (Figure 2). HD is performed after each injection to monitor treatment progress; when HD ceases to dilate the UO, appropriate coaptation has been achieved. At our institution, all procedures are performed on an outpatient basis and all patients receive preoperative antibiotic prophylaxis, which is continued until resolution of VUR has been confirmed. Success is defined as grade 0 VUR on a postoperative voiding cystourethrogram (VCUG), 1 to 3 months after a single treatment.

\section{RESULTS}

\section{Dynamic Hydrodistention Classification:}

All patients with documented VUR demonstrated HD. HD grade correlated significantly with VUR grade. Seventy-seven percent of patients with VUR grade $\mathrm{V}$ demonstrated $\mathrm{H} 3$, and $23 \% \mathrm{H} 2$, respectively. Contralateral ureters without evidence of VUR hydrodistended in $90 \%$, however, $\mathrm{H} 3$ ureters were only identified in $13 \%$. Patients with a history of recurrent UTIs and at least one negative VCUG, and no history of VUR, who underwent PIC (Positioning the Instillation of Contrast) cystography demonstrated HD grades similar to non-refluxing contralateral ureters. These patients are felt to have occult VUR and non-diagnostic preoperative micturition cystograms. However, ureters in patients with neither evidence of VUR nor UTI rarely hydrodistended $169 \% \mathrm{HO}, 31 \%$ $\mathrm{H} 1)$.

In our experience new contralateral VUR (NCVUR) occurs in $13.5 \%$ of cases (9). Girls younger than 5 years appeared to be at highest risk (21\%) compared to all other patients $(6.3 \%)$. Besides gender and age, HD grade was predictive of NCVUR occurrence; all ureters demonstrated $\mathrm{H} 2$ or $\mathrm{H} 3$. Because of the low morbidity of endoscopic injection, we have initiated a prospective study to determine the success in preventing contralateral VUR by prophylactically treating hydrodistending contralateral ureters $\mathrm{H} 2$ or $\mathrm{H} 3$ ). In the past 30 patients treated as such there has been no new contralateral VUR. The clinical utility of this approach, however, deserves further study.

\section{Double HIT Method:}

The modified STING procedure (HIT) was developed at our institution and introduced in 2002. The cure rate of 52 patients ( 80 ureters) treated with the standard STING procedure was compared to 70 patients (119 ureters) treated with the modified STING procedure. Overall success was $71 \%$ in the STING and $89 \%$ in the modified STING group. While decreasing success was seen with increasing VUR

\section{Dynamic Hydrodistention Classification}

HO

UO does not open

H1

UO opens slightly, cannot see into tunnel

$\mathrm{H} 2$

Can see into tunnel, not extravesical ureter
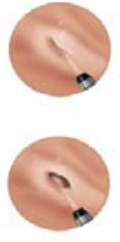

H3

Can see up extravesical ureter, ureteroscopy

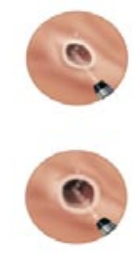

FIGURE 1. The dynamic hydrodistention classification represents distal ureteral dilation.
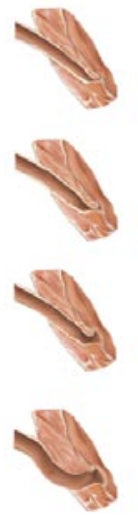

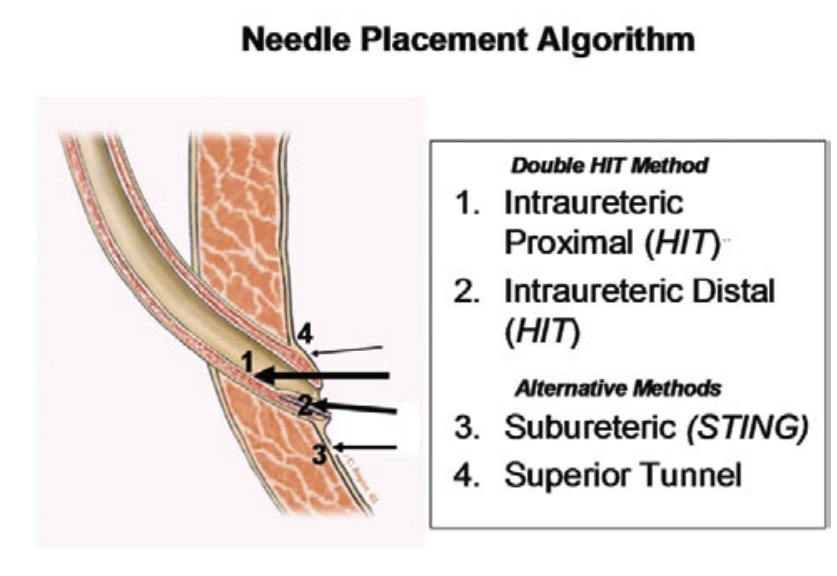

FIGURE 2. Needle placement algorithm for the endoscopic treatment of VUR. Sites 1 and 2 comprise the Double HIT method, while sites 3 and 4 are rarely used. 
grade in the STING group this did not occur in the modified STING group (Figure 3) (5).

The Double HIT method has been used at other centers with success rates of over $90 \%$ after one or two injections $(6,10)$. Despite the high cure rate after a single injection, approximately $10 \%$ of patients will present with persistent VUR. Fortunately, $40 \%$ of failures are down-graded to grade 1 and are observed, leaving only very few patients considered for further treatment. Treatment options for those with higher grades of VUR include continued antibiotic prophylaxis, repeat endoscopic treatment, or ureteral reimplantation. In our last 200 patients treated endoscopically, $90 \%$ of patients were cured Igrade 0 after 1 treatment), 93\% ureters cured, $97 \%$ patients improved, $94 \%$ off antibiotics, only $3 \%$ retreated, and only 1 patient went on to open surgery.

We studied the outcome of a second injection in 39 patients (53 ureters) who had failed prior treatment (11). The most common cystoscopic finding was bleb migration (distal or medial) and only in 5 cases the bleb could not be identified. All patients who had failed treatment demonstrated some degree of HD. The second injection was performed in identical fashion and was curative in $90 \%$.

The Double HIT method has not only been used for primary, but also complex cases of VUR, such as failed open reimplantation, duplicated ure-



FIGURE 3. Ureteral success rates for endoscopic treatment of VUR grades I to IV. Comparison between classic STING, modified STING technique (HIT), and Double HIT method. With the Double HIT method, success rates are statistically higher for grades 3 and 4 VUR compared to STING. ters, ureteroceles after puncture, retained ureteral stumps, neurogenic bladder, and ectopic ureters (12). Overall success was $68 \%$ after a single injection, however, varied greatly among groups. While only 1 of 7 patients with ectopic ureteral insertion at the bladder neck was cured, 7 of 9 patients with neurogenic bladder were successfully treated.

Paraureteral diverticula (PUD) associated with VUR have traditionally been treated with open reimplantation (13). A recent study demonstrated that the presence of PUDs did not affect the resolution rate of VUR, suggesting observation as an alternative for reimplantation (14). Our results indicate that endoscopic treatment of VUR associated with PUD is curative in $81 \%$ of patients. Large diverticular size and high injected volume were associated with treatment failure (15). However, when the PUD index (PUD diameter/Ureteral diameter) was less than 2.6, the success rate was $100 \%$.

\section{Complications:}

The most common complications following endoscopic treatment of VUR are NCVUR (13.5\%) and treatment failure (10\%). Less than $4 \%$ of children complained of moderate flank pain or emesis several hours after the procedure and all responded to analgesics (5). Gross hematuria, urinary retention, or febrile UTIs have not been observed. The most significant potential complication of endoscopic treatment for VUR includes a $0.6 \%$ risk of ureteral obstruction (16). Our obstruction rate is 4 ureters (2 patients) in over 1200 ureteral injections, or $<0.3 \%$. Factors that may increase the risk of obstruction include bladder dysfunction and markedly dilated ureters.

\section{DISCUSSION}

While the treatment algorithm for VUR remains controversial, surgical treatment has been proven effective in reducing VUR-related morbidity. Results of the American and European arm of the International Reflux Study in Children demonstrated a $50 \%$ decrease in the incidence of pyelonephritis, however, no effect on the occurrence of cystitis and new renal scars $(17,18)$.

Of all available surgical treatment options for VUR, endoscopic injection has become increasingly popular among pediatric urologists as well as parents. The procedure generally lasts less than 15 minutes and is performed on an outpatient basis. While cure rates are approaching those of open ureteral reimplantation, significant complications are rare $(6,10,16)$. Endoscopic treatment offers major advantages such as greater patient convenience, lower 
morbidity (e.g., pain, abdominal scar), and reduced cost $(19,20)$. Studies showed that the management decision was ultimately influenced by a parental preference for endoscopic treatment $(21,22)$. A more recent study demonstrated that both, patients and parents regarded endoscopic injection as the least bothersome aspect of VUR treatment followed by antibiotic prophylaxis and VCUG (23).

At present, few pediatric urologists rely on location or configuration of the UO to predict VUR resolution, and only occasionally is this information useful in determining the need for contralateral treatment during unilateral correction of VUR. Because NCVUR after ureteral reimplantation (10-20\%) typically resolves without manifestation of symptoms, concomitant reimplantation of the non-refluxing ureter is usually not recommended. However, preoperative resolution of contralateral VUR is an indication for bilateral ureteral reimplantation because of a $45 \%$ recurrence rate (24). Recently, PIC cystography was shown to identify VUR in patients with history of recurrent UTIs, but negative VCUG $(25,26)$. We have found that all ureters that reflux on PIC cystography also hydrodistend. Consequently, HD may serve three purposes: To aid in the needle placement, to confirm adequate injection, and to estimate the probability of NCVUR. Parents of children who developed NCVUR are understandably anxious and many will select endoscopic retreatment for the same reasons they initially chose minimally invasive treatment. The benefit of treating the contralateral ureter prophylactically is to avoid postoperative morbidity while utilizing the same surgical setting. This approach seems to be reasonable in select patients (e.g., girls younger than 5 years), however, may increase overall cost.

The HIT method is easy to learn and achieves cure rates of over $90 \%$ thus approaching the success of open reimplantation $(6,10)$. Treatment success is similar for all grades of VUR and may be explained by the Double HIT method per se $(5,6)$. Tandem midintramural and distal intramural injection sites coapt a longer segment of distal ureter. This anchors the bleb more efficiently and may prevent bleb migration. $\mathrm{HD}$ performed intermittently during injection assesses the ureterovesical junction for competency. Once a sufficient volume of bulking agent is implanted at the appropriate site, the ureter will cease to hydrodistend (and reflux). An intraoperative cure rate of 100\% should be achieved in all patients.

\section{Potential Future Applications:}

As the HIT method continues to be applied to complex cases of VUR and more outcome data become available, the indication for endoscopic treatment may exceed the scope of primary VUR. In the USA, for example, duplex ureters are no longer considered a contraindication for endoscopic treatment with Deflux $\circledast$ by the Food and Drug Administration. Treatment outcome analysis of primary and complex cases of VUR will establish predictors of treatment success and failure. Such data will aid in preoperative counseling and patient selection and paired with proper technique ultimately improve success rates of endoscopic treatment. As an example, treatment of selected patients with paraureteral diverticula proved to be successful and ureters with VUR Grade V, transplanted ureters with VUR (27), and VUR after puncture of ureteroceles may respond to the Double HIT method as well. Endoscopic treatment of VUR in adults with recurrent pyelonephritis is beginning to emerge as more adult patients are being appropriately evaluated for VUR. Finally, once more accurate predictors of VUR resolution or persistence become available, endoscopic treatment may be more frequently used as the primary treatment.

\section{CONCLUSIONS}

The dynamic hydrodistention classification reflects the competency of the ureterovesical junction and assists the pediatric urologist to decide which ureteral orifice and how much of bulking agent to inject. The Hydrodistention Implantation Technique achieves superior cure rates and is likely to become the method of choice for the treatment of primary and complex cases of vesicoureteral reflux.

\section{ABBREVIATIONS}

$\begin{array}{ll}\text { VUR } & \text { Vesicoureteral reflux } \\ \text { UTI } & \text { Urinary tract infection } \\ \text { STING } & \text { Subureteric teflon injection } \\ \text { HIT } & \text { Hydrodistention implantion technique } \\ \text { HD } & \text { Hydrodistention } \\ \text { UO } & \text { Ureteral orifice } \\ \text { VCUG } & \text { Voiding cystourethrography } \\ \text { PIC } & \text { Positioning the instillation of contrast } \\ \text { NCVUR } & \text { New contralateral vesicoureteral reflux } \\ \text { PUD } & \text { Paraureteral diverticulum }\end{array}$

\section{REFERENCES AND RECOMENDED READINGS ("of special interest, ${ }^{* *}$ of outstanding interest)}

1. JACOBSON, S.H.; HANSSON, S.; JAKOBSSON, B.: "Vesico-ureteric reflux: Occurrence and long-term risks". Acta Paediatr. Suppl., 88: 22, 1999. 
2. ELDER, J.S.; PETERS, C.A.; ARANT, B.S. Jr. y cols.: "Pediatric vesicoureteral reflux guidelines panel summary report on the management of primary vesicoureteral reflux in children". J. Urol., 157: 1846, 1997.

3. MATOUSCHEK, E.: "Die behandlung des vesikorenalen refluxes durch transurethrale einspritzung von teflonpaste". Der. Urologe. Ausg. A., 20: 263, 1981.

4. O'DONNELL, B.; PURI, P.: "Treatment of vesicoureteric reflux by endoscopic injection of teflon”. Br. Med. J. (Clin. Res. Ed.) 289: 7, 1984.

5. KIRSCH, A.J.; PEREZ-BRAYFIELD, M.; SMITH, E.A. y cols.: "The modified sting procedure to correct vesicoureteral reflux: Improved results with submucosal implantation within the intramural ureter". J. Urol., 171: 2413, 2004.

6. KIRSCH, A.J.; ELMORE, J.M.; MOLITIERNO, J. y cols.: "The double HIT methodology for the endoscopic correction of vesicoureteral reflux". Presented at the annual AUA meeting in Atlanta, Georgia 2006.

7. MOLITIERNO, J.A. Jr.; WATSON, J.M.; KIRSCH, A.J.: "Hydrodistention grading system for vesicoureteral reflux: Reproducibility and concordance". Presented at the annual AUA meeting in Anaheim, California 2007.

8. STENBERG, A.; LÄCKGREN, G.: "A new bioimplant for the endoscopic treatment of vesicoureteral reflux: Experimental and short-term clinical results". J. Urol., 154: 800, 1995.

9. ELMORE, J.M.; KIRSCH, A.J.; LYLES, R.H. y cols.: "New contralateral vesicoureteral reflux following dextranomer/hyaluronic acid implantation: Incidence and identification of a high risk group". J. Urol., 175: 1097, 2006.

10. YU, R.N.; ROTH, D.R.: "Treatment of vesicoureteral reflux using endoscopic injection of nonanimal stabilized hyaluronic acid/dextranomer gel: Initial experience in pediatric patients by a single surgeon". Pediatrics, 118: 698, 2006.

11. ELMORE, J.M.; SCHERZ, H.C.; KIRSCH, A.J.: "Dextranomer/hyaluronic acid for vesicoureteral reflux: Success rates after initial treatment failure". J. Urol., 175: 712, 2006.

12. PEREZ-BRAYFIELD, M.; KIRSCH,A.J.;HENSLE, T.W. y cols.: "Endoscopic treatment with dextranomer/hyaluronic acid for complex cases of vesicoureteral reflux". J. Urol., 172: 1614, 2004.

13. JAYANTHI, V.R.; McLORIE, G.A.; KHOURY, A.E. y cols.: "Extravesical detrusorrhaphy for refluxing ureters associated with paraureteral diverticula". Urology, 45: 664, 1995.

14. AFSHAR, K.; MALEK, R.; BAKHSHI, M. y cols.: "Should the presence of congenital paraureteral diverticulum affect the management of vesicoureteral reflux?". J. Urol., 174: 1590, 2005.

15. CERWINKA, W.H.; SCHERZ, H.C.; KIRSCH,
A.J.: "Endoscopic treatment of vesicoureteral reflux associated with paraureteral diverticula in children". J. Urol., 178:1.469, 2007.

16. VANDERSTEEN, D.R.; ROUTH, J.C.; KIRSCH, A.J. y cols.: "Postoperative ureteral obstruction after subureteral injection of dextranomer/hyaluronic acid copolymer". J. Urol., 176: 1593, 2006.

17. WEISS, R.; DUCKETT, J.; SPITZER, A.: "Results of a randomized clinical trial of medical versus surgical management of infants and children with grades III and IV primary vesicoureteral reflux (United States). The international reflux study in children". J. Urol., 148: 1667, 1992.

18. JODAL, U.; SMELLIE, J.M.; LAX, H. y cols.: "Ten-year results of randomized treatment of children with severe vesicoureteral reflux. Final report of the international reflux study in children". Pediatr. Nephrol., 21: 785, 2006.

19. KOBELT, G.; CANNING, D.A.; HENSLE, T.W. y cols.: "The cost-effectiveness of endoscopic injection of dextranomer/hyaluronic acid copolymer for vesicoureteral reflux". J. Urol., 169: 1480, 2003.

20. BENOIT, R.M.; PEELE, P.B.; DOCIMO, S.G.: "The cost-effectiveness of dextranomer/hyaluronic acid copolymer for the management of vesicoureteral reflux. 1: Substitution for surgical management". J. Urol., 176: 1588, 2006.

21. OGAN, K.; POHL, H.G.; CARLSON, D. y cols.: "Parental preferences in the management of vesicoureteral reflux". J. Urol., 166: 240, 2001.

22. CAPOZZA, N.; LAIS, A.; MATARAZZO, E. y cols.: "Treatment of vesico-ureteric reflux: A new algorithm based on parental preference". BJU Int., 92: 285, 2003.

23. STENBERG, A.; LÄCKGREN, G.: "Treatment of vesicoureteral reflux in children using stabilized non-animal hyaluronic acid/dextranomer gel (NASHA/DX): A long-term observational study". J. Pediatr. Urol., 3: 80, 2007.

24. ROSS, J.H.; KAY, R.; NASRALLAH, P.: "Contralateral reflux after unilateral ureteral reimplantation in patients with a history of resolved contralateral reflux". J. Urol., 154: 1171, 1995.

25. RUBENSTEIN, J.N.; MAIZELS, M.; KIM, S.C. y cols.: "The PIC cystogram: A novel approach to identify occult vesicoureteral reflux in children with febrile urinary tract infections". J. Urol., 169: 2339, 2003.

26. EDMONDSON, J.D.; MAIZELS, M.; ALPERT, S.A. y cols.: "Multi-institutional experience with PIC cystography- incidence of occult vesicoureteral reflux in children with febrile urinary tract infections". Urology, 67: 608, 2006.

27. CAMPBELL, J.B.; LENDVAY, T.S.; RISK, M.C. y cols.: "Endoscopic treatment of symptomatic refluxing renal transplant ureteroneocystostomies in children". Presented at the annual AUA meeting, Anaheim, California 2007. 